\title{
Transport Mechanisms of Nucleosides and Nucleoside Analogues Reverse Transcriptase Inhibitors in the Brain
}

\author{
Zoran B. Redzic ${ }^{1}$ and Sonja Misirlic Dencic ${ }^{2}$ \\ ${ }^{1}$ Department of Physiology, Faculty of Medicine, Kuwait University \\ 2Department of Biochemistry, School of Medicine, Belgrade University \\ ${ }^{1}$ Kuwait \\ ${ }^{2}$ Serbia
}

\section{Introduction}

Because of their hydrophilic natures, movements of nucleosides and many of their analogues across cellular membranes are mediated by nucleoside transporter (NT) proteins. Thus, NT proteins play an important role in physiological actions of nucleosides and in alterations of their function under various pathophysiological conditions. Also, these proteins are important for the therapeutic actions of some of synthetic nucleosides that have pharmacological actions and are thus used as drugs, including nucleoside analogues reverse transcriptase inhibitors (King et al., 2006, Zhang et al., 2007).

Before the "molecular biology" era, it was possible to explore nucleoside transport processes mainly by functional transport studies, which measured transcellular flux or cellular uptake of radiolabelled nucleosides. These early studies have identified two distinct transport processes in mammalian cells: the equilibrative bidirectional transport with lower affinity for naturally occurring nucleosides and the concentrative, unidirectional secondary active transport $\left(\mathrm{Na}^{+} /\right.$nucleoside cotransport) which revealed higher affinity for nucleosides (Hyde et al., 2004, Baldwin et al., 2004). Also, based on inhibition of these processes by synthetic analogues and based on substrate specificity and kinetics, it was recognized that both groups were heterogeneous: equilibrative nucleoside transport processes were further categorized as either nitrobenzylthioinosine (NBMPR)-sensitive (es) or NBMPR-insensitive (ei), while concentrative transport processes were categorized as either cit (concentrative, NBMPR insensitive, thymidine important substrate), cif (concentrative, NBMPR insensitive, formycin B important substrate) or cib (concentrative, NBMPR insensitive, broadly selective for purine and pyrimidine nucleosides) (Cass et al., 1998). Transport studies have also revealed that all these transport processes are not ubiquitously distributed in all mammalian cells; while equlibrative transport processes were more or less ubiquitous, concentrative transport processes were mainly found in epithelia, endothelial layers and in the liver (for an early review of nucleoside transport processes see Young and Jarvis 1983).

Development of molecular biology techniques has allowed identification of the proteins responsible for nucleoside transport processes (King et al., 2006). Purification and N-terminal sequencing of the es transporter from human erythrocytes enabled cloning a human placental 
cDNA encoding the corresponding transporter in 1996 (Griffiths et al., 1997a). cDNA clones encoding one of the ei-type transporter were subsequently isolated (Griffiths et al., 1997b, Crawford et al., 1998), while the remaining two ei-type transporters were identified and isolated as a result of the completion of the human genome project (Hyde et al., 2001). The isoforms corresponding to pyrimidine-, purine- and broadly selective concentrative nucleoside transport have been cloned and their structure was defined (Che et al., 1995, Ritzel et al., 1997, Wang et al., 1997, Gerstin et al., 2000, Patel et al., 2000, Ritzel et al., 2001).

All these proteins are members of two structurally unrelated protein families that are named (according to processes that they mediate) as equilibrative nucleoside transporter family (ENT) and concentrative nucleoside transporter family (CNT). These two familes are members of a superfamily of solute carriers (SLC), which includes facilitated transporters, ion-coupled transporters and exchangers that do not require ATP; ENT-family and CNTfamily are in humans known as SLC29 and SLC28, respectively.

\section{Molecular biology of nucleoside transporters}

So far, seven nucleoside transporter proteins were identified and described in mammals; four of them belong to the ENT family and are categorized as ENT1-4, while three of them belong to the CNT family and are categorized as CNT1-3.

\subsection{Equilibrative nucleoside transporter family}

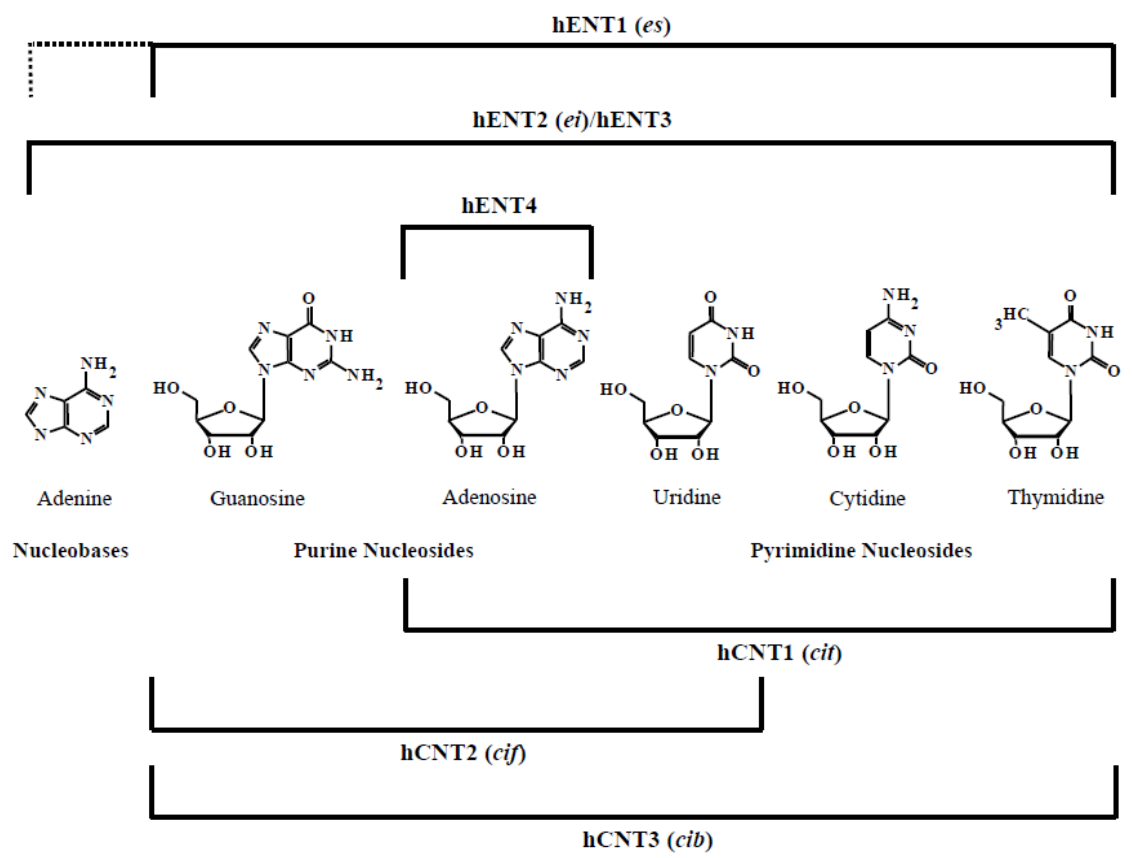

Fig. 1. Structures of naturally occurring nucleosides and nucleobases and their transport by human NT families. Reproduced with permission from Parkinson et al. (2011b). 
Equilibrative nucleoside transporters are present in many cell types and they transport a broad range of purine and pyrimidine nucleosides (Griffits et al., 1997a, Griffits et al., 1997b); hENT2 also transports nucleobases (Figure 1) (Yao et al., 2002). hENT3 functions predominantly in intracellular membranes (Baldwin et al., 2005), while hENT4 is also known as plasma monoamino transporter and transport monoamines in the brain and heart, while it transports adenosine only at low pH (Barnes et al., 2006, Zhou et al., 2007).

\subsubsection{Inhibition by synthetic analogues of nucleosides}

As it was mentioned above, early transport studies have recognized that nucleoside analogue NBMPR, when present in nanomolar concentrations, inhibited partially equilibrative transport. It is known today that this molecule is highly specific inhibitor of nucleoside transport via ENT1 protein, which mediates es-type transport activity. Because hENT1 is inhibited by nanomolar NBMPR, whereas hENT2, hENT3 and hENT4 are either unaffected by NBMPR or inhibited by micromolar concentrations, this synthetic analogue was extensively used for studies of ENT1 protein.

Both ENT1 and ENT2 are also inhibited by drugs such as dipyridamole and dilazep, which are also used as coronary vasodilators because by blocking equilibrative uptake of adenosine they increase extracellular concentration of this nucleoside, thereby producing vasodilation; dilazep, dipirydamole and NBMPR bind either to or adjacent to the outwardfacing region of the permeant-binding site (Baldwin et al., 2004). NBMPR and dipyridamole inhibit hENT1 with Ki values of $<5$ and $20 \mathrm{nM}$, respectively, and hENT2 with Ki values of $>1$ and $150 \mu \mathrm{M}$, respectively (Griffits et al., 1997a, Visser et al., 2002).

NBMPR is a membrane permeable nucleoside analogue; thus, if $\left[{ }^{3} \mathrm{H}\right] \mathrm{NBMPR}$ is used in a study, it will label all extracellular and intracellular binding sites, which makes relative quantification of extra- or intracellular binding sites impossible. To overcome this problem, a membrane-impermeant ENT1 ligand 5'-S-\{2-(1-[(fluorescein-5-yl)thioureido]hexanamido)ethyl\}-6-N-(4-nitrobenzyl)-5'-thioadenosine (FTH-SAENTA) was developed (Visser et al., 2007). This ligand was used for competitive binding studies with a logic behind its application that in the absence of FTH-SAENTA, $\left[{ }^{3} \mathrm{H}\right] \mathrm{NBMPR}$ will bind for all binding sites (intracellularly and extracellularly), while in the presence of FTH-SAENTA, only intracellular binding sites will be labeled. This approach enabled differentiation of intra- and extracellular $\left[{ }^{3} \mathrm{H}\right] \mathrm{NBMPR}$ binding sites and revealed that the intracellular distribution of hENT1 varies largely in different cell types (Paproski et al., 2008), and was mainly confined to nuclear membranes (Mani et al., 1998) and mitochondria (Lee et al., 2006). hENT1 also undergoes intensive trafficking and recycling (see below) which could be another explanation for relatively high proportion of $\left[{ }^{3} \mathrm{H}\right] \mathrm{NBMPR}$ binding sites present intracellualrly.

\subsection{Molecular properties, expression and mechanism of transport of ENTs}

Four ENT proteins have been encoded in the human, rat and mouse genomes and the abbreviations used for those proteins are hENTs, rENTs and mENTs, respectively (Griffits et al., 1997a, Griffits et al., 1997b, Baldwin et al., 2005, Barnes et al., 2006). They have been also produced as recombinant proteins in African clawed frog (Xenopus laevis) oocytes, that allowed detailed kinetic studies of transport processes; data obtained mainly by this technique, which describe kinetics of transport of naturally occurring nucleosides and nucleobases towards hENTs are presented in Table 1, while kinetic of transport of 
synthetic analogues that are used as reverse transcriptase inhibitors drugs by hENTs are presented in Table 2.

\begin{tabular}{|c|c|c|c|}
\hline Molecule & $\begin{array}{c}\text { Nucleoside } \\
\text { transporter that } \\
\text { mediate transport }\end{array}$ & $\begin{array}{c}\text { Available } \mathrm{Km} \text { values }(\mathrm{mM}) \\
\text { (transporter is indicated in } \\
\text { brackets) }\end{array}$ & Source \\
\hline \multicolumn{4}{|l|}{ Nucleosides } \\
\hline Adenosine & $\begin{array}{l}\text { hENT1-4 \& } \\
\text { hCNT1-3 }\end{array}$ & $\begin{array}{c}0.8 \text { (hENT4), } 0.008 \\
\text { (hCNT2), } 0.015 \text { (hCNT3) }\end{array}$ & $\begin{array}{l}\text { Griffits et al., 1997a; 1997b; } \\
\text { Baldwin et al., 2005; Barnes } \\
\text { et al., 2006; Ritzel et al., 1997; } \\
\text { 2001; Smith et al., } 2004\end{array}$ \\
\hline Guanosine & $\begin{array}{l}\text { hENT1-3, hCNT2, } \\
\text { hCNT3 }\end{array}$ & 0.04 (hCNT3) & $\begin{array}{l}\text { Griffits et al., 1997a; 1997b; } \\
\text { Baldwin et al., 2005; Ritzel et } \\
\text { al., 1997; } 2001\end{array}$ \\
\hline Inosine & $\begin{array}{l}\text { hENT1-3, hCNT1, } \\
\text { hCNT3 }\end{array}$ & $\begin{array}{c}0.005 \text { (hCNT1), } 0.05 \\
\text { (hCNT3) }\end{array}$ & $\begin{array}{l}\text { Griffits et al., 1997a; 1997b; } \\
\text { Baldwin et al., 2005; Ritzel et } \\
\text { al., 1997; } 2001\end{array}$ \\
\hline Uridine & $\begin{array}{c}\text { hENT1-3, hCNT1- } \\
3\end{array}$ & $\begin{array}{c}0.24 \text { (hENT1), } 0.2 \text { (hENT2), } \\
2.0 \text { (hENT3), } 0.03 \text { (hCNT1), } \\
0.04 \text { (hCNT2), } 0.015 \\
\text { (hCNT3)* }\end{array}$ & $\begin{array}{l}\text { Griffits et al., 1997a; 1997b; } \\
\text { Baldwin et al., 2005; Ritzel et } \\
\text { al., 1997; 200; Slugoski et al., } \\
\text { 2007, 2008; }\end{array}$ \\
\hline Cytidine & $\begin{array}{c}\text { hENT1-3, hCNT1, } \\
\text { hCNT3 }\end{array}$ & $\begin{array}{c}0.02 \text { (hCNT1), } 0.015 \\
\text { (hCNT3) }\end{array}$ & $\begin{array}{l}\text { Griffits et al., 1997a; 1997b; } \\
\text { Baldwin et al., 2005; Ritzel et } \\
\text { al., 1997; 200; Slugoski et al., } \\
\text { 2007, 2008; }\end{array}$ \\
\hline Thymidine & $\begin{array}{l}\text { hENT1-3, hCNT1, } \\
\text { hCNT3 }\end{array}$ & $\begin{array}{c}0.03 \text { (hCNT1), } 0.02 \\
\text { (hCNT3) }\end{array}$ & $\begin{array}{l}\text { Griffits et al., 1997a; 1997b; } \\
\text { Baldwin et al., 2005; Ritzel et } \\
\text { al., 1997; 200; Slugoski et al., } \\
\text { 2007, 2008; }\end{array}$ \\
\hline \multicolumn{4}{|l|}{ Nucleobases } \\
\hline Hypoxanthine & hENT2 & 0.7 & Yao et al., 2002 \\
\hline Adenine & hENT3, hENT3 & 1.1 (hENT2) & $\begin{array}{l}\text { Yao et al., 2002; Baldwin et } \\
\text { al., 2005, }\end{array}$ \\
\hline Thymine & hENT2 & 1.7 & Yao et al., 2002 \\
\hline Uracil & hENT2 & 2.6 & Yao et al., 2002 \\
\hline
\end{tabular}

Table 1. Selectivity of human nucleoside transporters (expressed in Xenopus oocytes) for naturally occurring nucleosides and nucleobases. Affinity of ligands for transporters is also presented as Michaelis constant $\mathrm{Km}$. ${ }^{*}$ This value is for $\mathrm{Na}+$ containing medium; in $\mathrm{H}+$ containing medium $\mathrm{Km}$ is 0.06 .

As mentioned above, the main location of ENT1 and ENT2 is the plasma membrane. However, immuno-staining and $\left[{ }^{3} \mathrm{H}\right] \mathrm{NBMPR}$ binding studies have often revealed a diffuse staining of cells. In example, when mouse CP was stained with these antibodies, obtained images revealed diffuse staining of $\mathrm{CP}$ epithelial cells in the case of mENT1 and disuse staining with a weak membrane staining of mENT2 (Parkinson et al., 2011). Such findings reflect, at least partially, abundant recycling and intracellular trafficking of those proteins. Studies that assessed NBMPR-binding in chromaffin cells suggested that NBMPR-binding 
disappears from the plasma membrane in about 5 hours, suggesting that ENT1 was internalized, with about $50 \%$ of this protein is recycled to the plasma membrane and the remaining protein probably degraded (Torres et al., 1992). A recent study has provided an important insight into the life cycle of human equilibrative nucleoside transporters (Nivillac et al., 2011). In this study, green fluorescence protein-tagged or FLAG- tagged hENT1 was transiently transfected into mammalian cells and the sequence of events regulating the hENT1 life cycle was studied; protein translocation to the plasma membrane was examined using fixed and live cell confocal microscopy (Nivillac et al., 2011). This study revealed that that the entire life cycle of the tagged-hENT1 protein was approximately 14 hours following translation, folding and ER export (Nivillac et al., 2011). After exiting the ER, hENT1 was translocated to the Golgi and glycosylated. Glycosylation probably plays a significant role in trafficking and function for a number of transporters including ENTs (Cai et al., 2005, Hendriks et al., 2004, Tanaka et al., 2004). hENT1 was then trafficked to the plasma membrane in association with the microtubule network in a variety of vesicles; in the plasma membrane hENT1 was co-localized with actin, which suggested that this transporter was anchored in the membrane by the actin cytoskeleton (Nivillac et al., 2011). This finding was consistent with previous observations for some other transporters, such as mouse GABA transporter 1 (Moss et al., 2009). After about an hour at the plasma membrane hENT1 internalized and interestingly only a proportion of the transporter population was recycled, which could indicate an efficient mechanism for fine-tuning, similar to what was described for the organic anion exchanger OAT1 (Zhang et al., 2008). Finally, internalized protein is degraded via the lysosomal pathway and observations suggest the complete life cycle of tagged hENT1 within these cells is approximately 14 hours.

In addition to studies on ENT 1 trafficking, efforts were also made to understand the mechanisms by which expression of ENT1 is modulated. A study investigated whether stress-activated kinases regulate ENT1 expression and function, using a mouse myeloid leukemic cell line as a model. It was revealed that Jun N-terminal kinase activation resulted in rapid loss of mENT1 function, mRNA expression and promoter activity; c-Jun decreased mENT1 promoter activity, which suggested a specific role for this transcription factor in mENT1 regulation. Overall, this study concluded that activation of JNK-cJun pathway negatively regulates $\mathrm{mENT1}$ (Leisewitz et al., 2011).

Current knowledge suggest that ENT3 is present in most tissues, including brain (Lu et al., 2004). It was found to co-localize with lysosomal markers and showed broad selectivity and low affinity towards the naturally occurring nucleosides and was unaffected by micromolar NBMPR, dipyridamole or dilazep (Baldwin et al., 2005). It was also indicated that hENT3 was found in mitochondrial membrane in several human cell lines (Govindarajan et al., 2009). Human and mouse ENT3 have a long hydrophilic N-terminus that contains a conserved characteristic of endosomal and /or lysosomal targeting sequences (Baldwin et al., 2005). Thus, when expressed in Xenopus oocytes, hENT3 and mENT3 did not have functional role in transport across the plasma membrane unless the $\mathrm{N}$-terminus was modified (Baldwin et al., 2005). This transporter is activated at low $\mathrm{pH}$ (proton-dependent activation), which may be an important feature for its localization in acidic environment, like lysosomes and mitochondria. A physiological function of this transporter could be to transport nucleosides and nucleobases that are produced by nucleic acid breakdown in lysosomes and to provide material for mitochondrial DNA synthesis. A recent study revealed that hENT3 mRNA was the most abundant when compared to other hNTs mRNAs in human choroid plexus (Redzic et al., 2010). 
Immunocytochemistry and immunonlotting have detected presence of ENT4 in human and mouse brain and in human, mouse and rat heart (Barnes et al., 2006). hENT4 revealed selectivity for adenosine, while mENT4 also shows affinity to transport adenine; affinity for substrates appears to be low and proton-dependent (Barnes et al., 2006). hENT4 is unaffected by as much as $1 \mu \mathrm{M}$ NBMPR and only partially inhibited by micromolar dipyridamole. This transporter is also known as plasma membrane monoamine transporter (PMAT); experimental data also suggest that transport of substrates by $\mathrm{h} / \mathrm{mENT4}$ is inhibited by organic cation transporter inhibitor 1,1'-diethyl-2,2'-cyanine (decynium-22) and dopamine transporter inhibitor (Barnes et al., 2006). Structure analysis suggested that human and mouse ENT4 are closely related to ENT3 in a fruit fly (Drosophila melanogaster), rather than to human and mouse ENT1, a data that could suggest early divergence from other mammalian ENTs during the evolution (Barnes et al., 2006).

\subsection{Molecular properties of transport by concentrative nucleoside transporters}

CNT1 and CNT2 proteins are found primarily in epithelial tissues of small and large intestine, kidney, liver, heart (CNT2), pancreas (CNT2), skeletal muscle (CNT2), brain endothelial cells (CNT2) and choroid plexus (CNT2) (Gray et al., 2004, Redzic et al, 2005). CNT3 protein is found the pancreas, trachea, bone marrow, mammary gland and choroid plexus (Gray et al, 2004, Redzic et al., 2005, Redzic et al., 2010). Structure of human, rat and mouse CNTs is largely identical, with hCNT1 and rCNT1 being $83 \%$ identical at protein level, hCNT2 and rCNT2 being $81 \%$ identical and hCNT3 and $\mathrm{mCNT} 3$ being $78 \%$ identical (Gray et al., 2004). CNT1 is pyrimidine selective, but also transports adenosine with highaffinity and low capacity (Ritzel et al., 2001); CNT2 transport purine nucleosides and pyrimidine uridine (Wang et al., 1997, Ritzel et al., 1998), while CNT3 is broadly selective and transports both purine and pyrimidine nucleosides (Ritzel et al., 1997).

Membrane transport of nucleosides by CNTs takes place in symport with $\mathrm{Na}^{+}$and/or $\mathrm{H}^{+}$. Thus, this process is electrogenic, since an uncharged particle (i.e. nucleoside) is transported together with an ion. If these transporters are produced as functional recombinant proteins in a heterologous expression system (i.e. Xenopus oocytes), molecular properties of nucleoside transport could be studied by steady-state electrophysiology techniques, using the two microelectrode voltage-clamp (Smith et al., 2005).

Using this approach, it has been shown that hCNT1 and hCNT2 are coupling nucleoside translocation to cotransport of $\mathrm{Na}^{+}$(i.e. they are Na+-specific) (Smith et al., 2004), while hCNT3 couples nucleoside translocation to cotransport of $\mathrm{Na}^{+}$and $\mathrm{H}^{+}$(Smith et al., 2005). For hCNT1 and hCNT2 the coupling ratio is $1: 1$, while for hCNT3 the $\mathrm{Na}^{+}$:nucleoside coupling ration is 2:1, while the $\mathrm{H}^{+}$:nucleoside coupling ratio is 1:1 (Smith et al., 2007).

Pre-steady-state currents measurements in hCNT-producing Xenopus oocytes revealed the transporter valence to be -1 and -2 for hCNT1 and hCNT3, respectively; it was estimated that $10^{10}$ to $10^{11} \mathrm{hCNT} 2$ and hCNT3 transporters were present per oocyte (Smith et al., 2004, 2005). The sequence of events during CNTs-mediated transport has been elucidated partially. First $\mathrm{Na}^{+}$and/or $\mathrm{H}^{+}$bind to hCNT1 or hCNT3 and this event increases the affinity of these proteins for nucleoside substrates; in the case of hCNT3, after nucleoside binding it binds second $\mathrm{Na}^{+}$(Smith et al., 2004, 2005). Thus, the $\mathrm{Na}^{+}$coupling ratio for hCNT3 (2:1) if compared to the $\mathrm{Na}^{+}$coupling ratio for hCNT1 (1:1) suggests that the former one is more capable to transport nucleosides against their concentration gradient. Interestingly, $\mathrm{H}^{+}$ binding for hCNT3 changes its conformation (when compared hCNT3 with $\mathrm{Na}^{+}$ion bound), 
so $\mathrm{Na}^{+}$-coupled hCNT3 transports purine and pyrimidine nucleosides and also nucleoside analogue reverse transport inhibitor zidovudine, while $\mathrm{H}^{+}$-coupled hCNT3 is selective for pyrimidines and does not transport zidovudine (Smith et al, 2005).

\section{Distribution of nucleoside transporters in the brain}

Expression of nucleoside transporters in the brain was mainly explored by techniques in situ (i.e. ligand binding and immunostaining of brain slices or various brain regions), immunoblotting and by in vitro techniques (i.e. cell cultures). Surprisingly, those approaches often produced conflicting results. In example, an in situ study that used polyclonal antibodies against rENT1 and rENT2 revealed that those transporters were present in all neurons explored, while only some astrocytes showed rENT1 staining, while rENT2 staining on astrocytes was observed only sporadically (Alanko et al., 2006) Contrary to this finding, a study that used immunoblotting on rat astrocytes in primary culture has clearly revealed that both rENT1 and rENT2 were present (Redzic et al., 2010b). Those discrepancies could be partially explained by dedifferentiation of cells in culture.

\subsection{Equilibrative nucleoside transporter 1}

ENT1 was by far the most well studied nucleoside transporter in the brain. This was largely because a specific ligand NBMPR that binds to this protein with high affinity was available (see above). Thus, most of our current knowledge was gained on studies that used brain sections that were incubated with $\left[{ }^{3} \mathrm{H}\right] \mathrm{NBMPR}$, with unlabelled NMBPR being used to define non-specific binding and with autoradiography film being used to visualize the distribution of specific binding sites. These studies have revealed localized distribution of binding sites for this radioligand, indicating uneven distribution of ENT1 in rodent brain, which was unexpected because a general view was that ENT1 is an ubiquitous nucleoside transporter. High $\left[{ }^{3} \mathrm{H}\right] \mathrm{NBMPR}$ binding was detected in thalamus and superior colliculus, while low binding was detected in hippocampus, cerebral cortex and cerebellum; other regions show no ligand binding (Geiger et al., 1984, Parkinson et al., 1996, Bailey et al., 2002). Contrary to this, immunocytochemistry studies has revealed more even distribution of this transporter throughout the brain, with a strong signal being detected in cerebral cortex, hippocampus, striatum and cerebellum (Alanko et al., 2006).

In situ hybridization studies that detected distribution of mRNA encoding ENT1 have revealed its wide distribution in the brain with a strong signal being detected from hippocampus, cerebellum, cerebral cortex and striatum (Anderson et al., 1999). This technique has also detected ENT1 mRNA in astrocytes, and choroid plexus epithelial cells.

Distribution of hENT1 in human brain has also been investigated and these studies have revealed that hENT1 mRNA was very abundant in caudate nucleus, amygdale, hippocampus and thalamus, while it was scarce in substantia nigra; like in the rodent brain, there was no correlation between those findings and hENT1 protein distribution, which was greatest in several areas of cerebral cortex, much lower in thalamus and basal ganglia, and scarce in hippocampus and cerebellum (Jennings et al, 2001). However, in the human brain, a positive correlation was shown between hENT1 distribution and adenosine A1 receptors distribution (Jennings et al, 2001), which was opposite to findings in the rodent brain, where a correlation between rENT1 and A1 receptors distribution was either poor (Geiger et al., 1984, Bailey et al., 2002) or negative (Parkinson et al., 1996). 


\subsection{Equilibrative nucleoside transporter 2}

Since there is no high-affinity ligand for ENT2 available so far, studies that explored distribution of ENT2 in the brain employed a strategy in which brain slices were probed with radiolabelled dipyridamole, a ligand that binds more or less equally to ENT1 and ENT2 and with radiolabelled dipyridamole in the presence of unlabelled NBMPR, which in nanomolar concentration binds to ENT1 (and thus block dipyridamole binding for this transporter). Under those circumstances, the detected radiligand binding that was not blocked by the presence of nanomolar NBMPR but was blocked by micromolar NBMPR could be largely attributed to ENT2. A problem with this strategy is that dipyridamole is very lipophilic and thus binds unspecifically, which limits usefulness of data drawn from these studies. Data available so far suggest that for guinea pig CNS membranes $40-50 \%$ of [3H]dipyridamole binding could be attributed to ENT2 (Jones and Hammond, 1992).

Some studies have measured uptake of $\left[{ }^{3} \mathrm{H}\right]$ adenosine in the presence of nanomolar NBMPR and in the presence of dipyridamole. The logic behind these studies was that adenosine cellular uptake via rENT1 would be inhibited by the presence of nanomolar NBMPR, while adenosine upake via both transporters would be inhibited in the presence of dipyridamole, so a difference between uptake rates under those two conditions could be credited to uptake via rENT2. Using this strategy it was revealed that $\left[{ }^{3} \mathrm{H}\right]$ adenosine uptake by primary cultures of rat cerebral neurons and astrocytes was inhibited by $>20$ and $>30 \%$ by the presence of nanomolar NBMPR, respectively, while dipyridamole inhibited more than $80 \%$ of uptake, which indicated that rENT2 was functionally more abundant than rENT1 in these cells (Parkinson et al., 2005).

Immunocytochemistry revealed that rENT2 had a widespread distribution of in rat brain and that this distribution largely overlapped with distribution of rENT1 (Alanko et al., 2006). Distribution of rENT2 mRNA in rat brain was widespread and more abundant than distribution of rENT1 and mRNA was localized in cerebral cortex, striatum, thalamus, hippocampus and cerebellum, choroid plexus and blood vessels (Anderson et al., 1999). Primary cultures of rat neurons and astrocytes also had more abundant mRNA for rENT2 than for rENT1, as revealed by quantitative RT-PCR (Parkinson et al., 2006).

\subsection{Other equilibrative nucleoside transporters}

It was revealed that rat and mouse brain express mRNA for ENT3 [Baldwin et al., 2005, Parkison et al., 2006). Human choroid plexus expressed abundantly hENT3 mRNA (Redzic et al., 2010a). However, so far there are no data demonstrating functional role of this transporter in the brain. Human, mouse and rat brain also express ENT4 mRNA that was widespread in neurons [Barnes et al., 2006, Parkinson et al., 2006, Vialou et al., 2007). Immunocytochemistry did not reveal presence of this transporter in astrocytes (Dahlin et al., 2007).

\subsection{Concentrative nucleoside transporter 1}

Amount of CNT1 mRNA in the brain was less abundant than in epithelia (Lu et al., 2004). In the brain, CNT1 mRNA was detected by in cerebral cortex, hypothalamus, hippocampus, cerebellum and choroid plexus (Lu et al., 2004). Rat astrocytes in primary culture express rCNT1 transcript, as revealed by RT-PCR, but the abundance was very low; however, rCNT1 protein was detected in these cells by immunoblotting (Redzic et al. 2010b). 


\subsection{Concentrative nucleoside transporter 2}

The relative abundance of CNT2 mRNA in the rodent brain was low when compared to epithelial, barrier-forming layers, like intestine ( $\mathrm{Lu}$ et al., 2004). RT-PCR revealed that distribution of rENT2 mRNA was widespread and uniform in all rat brain regions examined (Anderson et al., 1996). In situ hybridization revealed that neurons in the hippocampus, basal ganglia, cerebral cortex, hypothalamus and cerebellum had intense signal (GuillenGomez et al., 2004). Interestingly, in situ studies showed that CNT2 mRNA was not present in astrocytes (Guillen-Gomez et al., 2004), but it was present in primary cultures of mouse and rat astrocytes and functional activity of this transporter in those cells was revealed (Nagai et al., 2005, Peng et al., 2005, Redzic et al., 2010b). However, rCNT2 protein was absent from rat astrocytes in primary culture (Redzic et al., 2010b).

\subsection{Concentrative nucleoside transporter 3}

Rat and mouse brain revealed low abundance of CNT3 mRNA (Lu et al., 2004). mRNA was not detectable in primary cultures of rat neurons and astrocytes (Nagai et al., 2005, Redzic et al., 2010b), but surprisingly rCNT3 protein was detected in cultured rat astrocytes (Redzic et al., 2010b). Human brain contained hCNT3 transcripts, but with low abundance (Ritzel et al., 2001).

\subsection{Expression of nucleoside transporters in the brain of ENT1-knockout mice}

Genetic variation of equilibrative nucleoside transporters are very rare, which indicated that function of those proteins could be essential for the survival; thus, efforts were made to produce ENT1-knockout mouse, in order to analyze effects of mENT1 absence on homeostasis and on expression of other nucleoside transporters (for the procedure Choi et al., 2004). Surprisingly, it was found that mice lacking mENT1 have similar pattern of distribution of other nucleoside transporters as wild-type mice. A study that examined if the ENT1-null mouse heart was cardioprotected in response to ischemia showed that ENT1-null mouse hearts showed significantly less myocardial infarction (after 30-min coronary occlusion) compared with wild-type littermates (Rose et al., 2010). Wild-type adult mouse cardiomyocytes express predominantly ENT1 and this transporter was primarily responsible for purine nucleoside uptake; thus, ENT1-null cardiomyocytes exhibit severely impaired nucleoside transport that could cause a higher increase in extracellular adenosine following ischemia than in wild-type mouse (Rose et al., 2010). However, adenosine receptor expression profiles and expression pattern of ENT2, ENT3, and ENT4 were similar in cardiomyocytes isolated from ENT1-null adult mice compared with cardiomyocytes isolated from wild-type littermates (Rose et al., 2010). Quantitative RT-PCR was used to investigate mENT1-4 and mCNT1-3 transcripts in wild-type and ENT1-null mouse brain (Parkinson et al., 2011). This study showed that the most abundant transporter in wild-type brain was mENT1, while mENT2 was most abundant in the mENT1-null brain (Parkinson et al., 2011). Beside this difference, the NT expression patterns were similar between the wildtype and mENT1-null whole brain. This indicated that absence of mENT1 could be at least partially compensated by increased expression of mENT2 (Parkinson et al., 2011).

\section{Nucleoside transporters at the blood-brain barrier and at the blood- cerebrospinal fluid barrier}

A constant and well-controlled composition of the extracellular fluid in the central nervous system (CNS) is essential for efficient neuronal processing. To control the brain microenvironment, the endothelial blood-brain barriers (BBB) exists in all vertebrates, except 
for a few fish species (Bundgaard and Abbott, 2008). The BBB and the blood-cerebrospinal fluid barrier (BCSFB) are formed by brain endothelial cells (BECs) and choroid plexus (CP) epithelial cells, respectively (for a review see Redzic, 2011). The BBB and the BCSFB are not only anatomical barriers, but also dynamic tissues that express multiple transporters, receptors and enzymes.

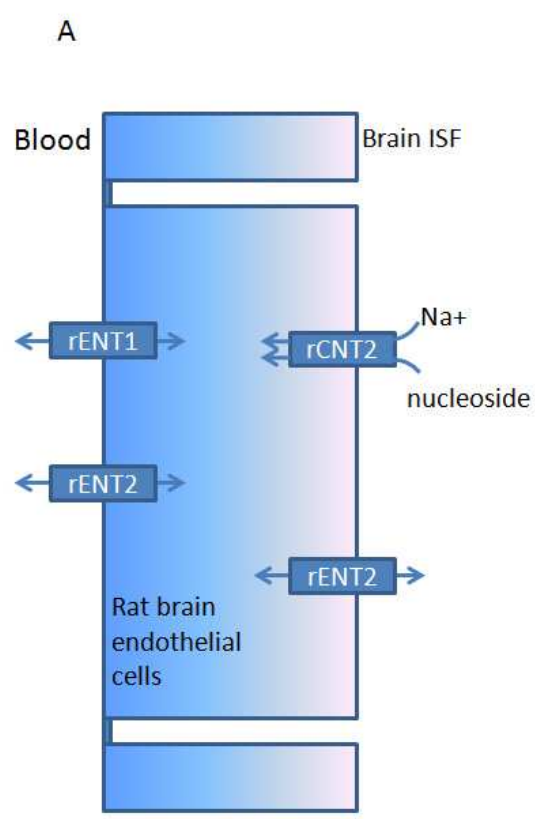

B

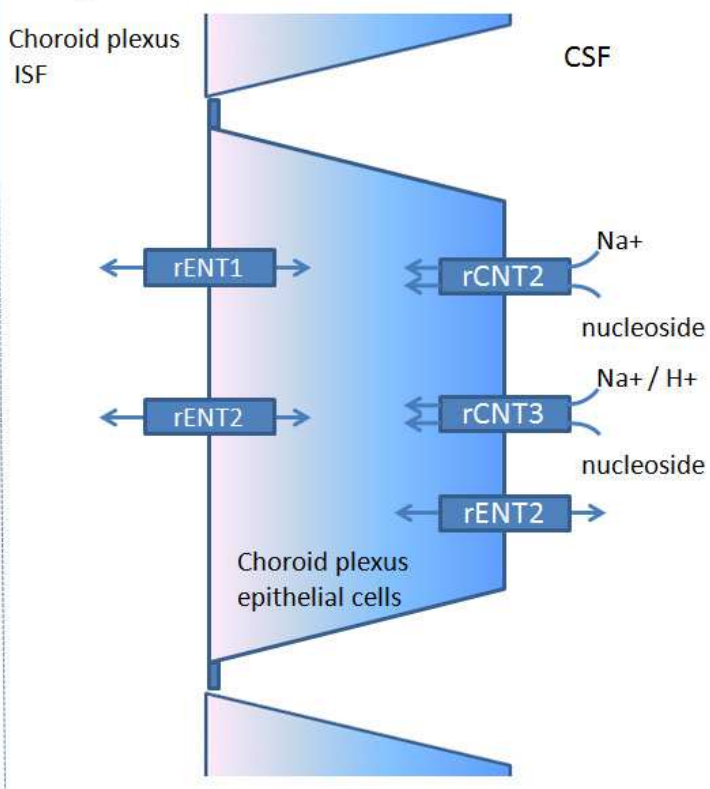

Fig. 2. A proposed distribution of rENTs and rCNTs in rat brain endothelial cells (A) and in rat choroid plexus epithelial cells (B). A model was proposed based on in vitro data, when rat brain endothelial cells and rat choroid plexus epithelial cells were grown as monolayers on permeable supports (Redzic et al., 2005, Redzic et al., 2006).

The two main functions of these barriers are to impede free diffusion between brain fluids and blood and to provide transport processes for essential nutrients, ions and metabolic waste products. Presence of tight junctions between adjacent brain endothelial cells or choroid plexus epithelial cells restrict paracellular diffusion across these cellular layers. Thus, hydrophilic molecules (like naturally occurring nucleosides) cannot readily enter brain ISF or CSF by simple diffusion and must be transferred across the layer by ENTs and CNTs located in these cellular layers. On the other hand, many synthetic nucleosides and some nucleobases are scarcely soluble in water and they are more soluble in lipids; such molecules can diffuse into lipid bilayers, but both the BBB and the BCSFB use ATP-driven transporters that mediate efflux of lipophilic molecules (Miller, 2010).

Adenosine transport across the BBB was investigated in vivo; efflux transport studies (brain intracellular fluid (ISF) to blood transport) and influx transport studies (blood to brain ISF transport) were performed following intracerebral and intracarotid injections of 
$\left[{ }^{14} \mathrm{C}\right]$ adenosine, respectively, together with a $\left[{ }^{3} \mathrm{H}\right]$ vascular space marker (Isakovic et al., 2004). This study revealed that estimated BBB efflux clearance of $\left[{ }^{14} \mathrm{C}\right]$ radioactivity after intracerebral injection of $\left[{ }^{14} \mathrm{C}\right]$ adenosine was almost threefold higher than the estimated $\mathrm{BBB}$ influx clearance of radioactivity after intracarotid injection of this molecule (Isakovic et al., 2004). However, if the values of Vmax and $\mathrm{Km}$ calculated from this study plus the reported brain ISF adenosine concentration (Melani et al. 1999) are inserted into the Michaelis equation, an estimated velocity of BBB efflux transport in vivo was 100 -fold lower than the reported rate of uptake of adenosine into neurones/glia (Lawrence et al. 1994) and the rate of phosphorylation by adenosine kinase inside the cells (Phillips and Newsholme 1979), which indicates that adenosine BBB efflux transport does not play an important role in adenosine homeostasis under resting physiological conditions. This study also revealed that most $\left[{ }^{14} \mathrm{C}\right]$ radioactivity in plasma appeared with the HPLC peaks for adenosine metabolites adenine and hypoxanthine after the intracerebral injection of $\left[{ }^{14} \mathrm{C}\right]$ adenosine, while negligible amounts appeared within the adenosine peak; this suggested that the brain capillary endothelial cells appear to act as an enzymatic barrier for adenosine, rapidly degrading this molecule (Isakovic et al., 2004). Using the same technique, the BBB efflux transport of other purines was studied in vivo after the intracerebral injection of radiolabelled purines; this study has revealed rapid BBB efflux clearance of hypoxanthine and adenine (Isakovic et al., 2002).

Rat brain endothelial cells (RBECs) were also grown as primary monocultures on permeable supports (filters); under those circumstances they developed transcellular electrical resistance that was sufficient to provide separate studies of cellular uptake with upper chamber as a donor and with lower chamber as a donor (Redzic et al., 2005). This study revealed that RBECs expressed rENT1, rENT2 and rCNT2 mRNA and protein; interestingly, rCNT2 was the most abundant at both transcript and protein level. Transcripts for rCNT1 and rCNT3 were either absent or of very low abundance. [ $\left.{ }^{3} \mathrm{H}\right]$ adenosine transport data revealed that the cellular uptake of this nucleoside was sodium-dependent only when lower chamber was a donor. Sodium-independent uptake of adenosine was observed across both membranes, consistent with detection of both rENT1 and rENT2 proteins in these cells, but the pattern of inhibition by NBMPR suggested that rENT1 was confined to the membranes facing the upper chamber, whereas rENT2 was probably present in both membrane domains (Redzic et al., 2005). When RBEC are grown on permeable supports, the cellular membranes facing the lower and upper chambers display some of the characteristics of the in vivo basolateral (brain ISF-facing) and apical (blood-facing) membranes, respectively (Reichel et al. 2003). Therefore, findings from this study suggested that concentrative adenosine uptake at the BBB in vivo may be limited to the brain ISF-facing membrane, whereas transport via ENT1 occurs only on the opposite side. Such a pattern of nucleoside transporter distribution (presented in Figure 2A) combined with the detected rapid metabolism of adenosine in endothelial cells (Isakovic et al. 2004) may suggest that the role of the BBB is to remove adenosine from the brain ISF, rather than to mediate uptake of this purine nucleoside from the circulation.

Primary cultures of sheep CP epithelial cells (CPEC) were also grown as monolayers on permeable supports (Redzic et al., 2006) and these cells expressed some features typical of the CPEC in situ; they developed relatively high transepithelial electrical resistance which was accompanied by low paracellular permeability, a property that enabled the use of this model for studies of transcellular transport of radiolabelled adenosine. Transcellular permeability of these monolayers towards $\left[{ }^{14} \mathrm{C}\right]$ adenosine was surprisingly low, but when adenosine 
intracellular metabolism was inhibited, there was more than a five-fold increase in the transcellular permeability for $\left[{ }^{14} \mathrm{C}\right]$ adenosine, which indicated that intracellular phosphorylation of adenosine into nucleotides and/or its degradation into nucleobases that show different kinetic properties to adenosine might be the cause of low transcellular permeability. This study also applied HPLC analysis with simultaneous detection of radioactivity and revealed that $\left[{ }^{14} \mathrm{C}\right]$ radioactivity which appeared in the acceptor chamber after the incubation of CPEC monolayers with $\left[{ }^{14} \mathrm{C}\right]$ adenosine in the donor chamber, mostly was present as $\left[{ }^{14} \mathrm{C}\right]$ hypoxanthine, which indicated that sheep CPEC in primary culture, similarly to the rat brain endothelial cells, act as an enzymatic barrier towards adenosine (Redzic et al., 2006). Uptake studies on this model revealed that $\left[{ }^{14} \mathrm{C}\right]$ adenosine concentrative uptake was confined to the apical ('CSF') side of these cells, indicating uneven distribution of nucleoside transporters and a possible role in removing adenosine from the CSF.

A study on sheep CPEC in primary culture, grown on permeable supports, gave an insight on nucleobase transport and metabolism in the CPEC; it was revealed that uptake of $\left[{ }^{14} \mathrm{C}\right]$ hypoxanthine by the apical side was partially $\mathrm{Na}^{+}$-dependent and partially $\mathrm{Na}^{+}-$ independent, the latter process being partially mediated by ENT2. Hypoxanthine was metabolized inside the CPEC through the action of hypoxanthine-guanine phosphoribosyl transferase, producing nucleotides and the nucleoside inosine. Some hypoxanthine and inosine left CPEC through the opposite side of the cell. This might suggest that the uptake of hypoxanthine by the apical side of the sheep CPEC could serve two important functions in vivo, which was to provide material for local demands of the CPE for nucleotides through the salvage pathways, as well as to remove excess hypoxanthine to the $\mathrm{CP}$ interstitial fluid. The same model was also used to grow primary cultures of rat CPEC; RT-PCR and Western blots of revealed the presence of rENT1, rENT2, rCNT2 and rCNT3, but not the pyrimidine-preferring rCNT1 (Redzic et al., 2005). Adenosine uptake by these cells showed a polarized distribution of $\mathrm{Na}^{+}$-dependent transport of $\left[{ }^{14} \mathrm{C}\right]$ adenosine at the apical cell surface that could be attributed to rCNT2 and/or rCNT3. $\mathrm{Na}^{+}$-independent transport that was partially NBMPR-sensitive at the basolateral cell surface which could be attributed to the presence of rENT1 and rENT2 [91]. The remaining adenosine uptake at apical cell surfaces that was sodium-independent was NBMPRinsensitive, thus could be attributed to rENT2 (Figure 2B) (Redzic et al., 2005).

Expression of nucleoside transporters at transcript level and nucleoside uptake was studied in isolated portions of human lateral ventricle choroid plexuses that were obtained during neurosurgery (Redzic et al., 2010a). Quantitative RT-PCR revealed that transcripts for hENT1-3 and hCNT3 were present with mRNA for hENT3 being the most abundant. hCNT1 and hCNT2 transcripts were absent or present at very low abundance. Human CP samples took up radiolabelled inosine by both concentrative and equilibrative processes. However, the equilibrative uptake was mediated only by hENT2, while hENT1 transport activity was absent, which could suggested either that this protein was absent in the human $\mathrm{CP}$ or that it was confined to the basolateral side of the $\mathrm{CP}$ epithelium (which did not come in contact with uptake buffer in this study) (Redzic et al., 2010a).

Thus, several lines of evidences suggest that polarized distribution of nucleoside transporters at the BBB and in the $\mathrm{CP}$ epithelium, with CNTs located on sides facing brain extracellular fluids (ISF and CSF) and equlibrative transport across the opposite, blood facing side, may play an important role in the removal of nucleosides from brain fluids. Also, it appears that brain endothelial cells represent an enzymatic barrier towards at least some nucleosides and nucleobases; this enzymatic activity may further impede blood to brain transport. 


\section{Expression of NTs in neurons and astrocytes and the role of these transporters in nucleoside homeostasis in the brain}

Adenosine concentration in the brain extracellular fluid (ECF) depends on three processes: (a) its formation in neurons (Zamzow et al., 2008, Parkinson et al. 2005) and transport from neurons across the plasma membrane to the ECF; (b) its formation extracellularly through the action of soluble or membrane bound ecto-nucleotidases on ATP that is released from astrocytes (Parkinson and Xiong, 2004) and uptake by astrocytes, a process that is normally followed by intracellular conversion to inosine and hypoxanthine (Zamzow et al., 2008). However, relative contributions of intracellular and extracellular formation are not clear. A classical view suggests that adenosine is mainly formed intracellularly as a consequence of ATP hydrolysis; cellular concentrations of ATP are manifolds higher than concentrations of adenosine (Fredholm et al., 2005), so a small increases in ATP degradation can cause a large increase in adenosine concentration. Once it is formed, intracellular adenosine leaves cells by facilitated diffusion via ENTs. There are several lines of evidences showing that neurons in primary culture, after being exposed to hypoxia / glucose deprivation released adenosine and inosine (Parkinson et al., 2005, Parkinson and Xiong, 2004) and also release these two nucleosides when they were treated with the glutamate receptor agonist N-methyl-Daspartate (Zamzow et al., 2008, 2009), while dipyridamole, a non-selective ENT1/2 inhibitor in rat cells, inhibited this release.

A non-classical view suggests that adenosine is mainly formed extracellularly by a series of reactions catalyzed by ecto-nucleotidases following cellular release of ATP (Dunwiddie and Masino 2001). Evidences suggest that rat cortical astrocytes in primary cultures, when exposed to hypoxia, release adenosine and inosine, but that release was not blocked by dipyridamole, suggesting that transport across the plasma membrane did not play a role in this release (Parkinson and Xiong, 2004). Thus, it appears that in the brain both pathways for adenosine production are present, with neurons releasing mainly adenosine (as a product of ATP hydrolysis) and astrocytes releasing ATP that is hydrolysed extracellularly to adenosine (Parkinson et al., 2005). Furthermore, data suggest that adenosine that was produced by neurons was mainly taken up by astrocytes and metabolized intracellularly to hypoxanthine (Zamzow et al., 2008); hypoxanthine was then released in the ISF. The net effect of this process is that adenosine neuromodulatory action was time-limited, since adenosine was rapidly converted to nucleobase hypoxanthine, which has no effect in cell signaling.

A study that explored the role of neuronal equilibrative NTs in adenosine influx and efflux during cerebral ischemia has used mice with neuronal expression of hENT1 and wild type littermates to compare responses to in vitro and in vivo hypoxic / ischemic conditions (Zhang et al., 2011). Hypoxia / oxygen-glucose deprivation produced greater inhibition of excitatory neurotransmission in slices from wild type mice than from mice expressing hENT1. Presence of NBMPR abolished these differences, which altogether indicated that neuronal equilibrative NTs reduce hypoxia / ischemia-induced increase in extracellular adenosine concentrations (Zhang et al., 2011). This may suggest that that inhibition of neuronal adenosine transporters may beneficial for the treatment of cerebral ischemia.

A recent study has revealed that hypoxia and glucose deprivation can also affect expression of nucleoside transporters in rat astrocytes in primary culture. Those cells expressed rENT1, rENT2, rCNT1 and rCNT3; rCNT2 was present at transcript level but the protein could not be detected (Redzic et al., 2010b). Hypoxia and glucose deprivation (60 min) was accompanied by an increase in adenosine and ATP concentration in culture medium and 
caused a decrease in the expression of rENT1 in astrocytes; hypoxia and glucose deprivation followed by $1 \mathrm{~h}$ recovery period caused a decrease in the expression of rENT1 and rENT2 and a decrease in equilibrative cellular uptake of [ $\left.{ }^{3} \mathrm{H}\right]$ adenosine by astrocytes (Redzic et al., $2010 \mathrm{~b})$. Astrocyte cultures that were subjected to $1 \mathrm{~h}$ hypoxia and glucose deprivation that was followed by $1 \mathrm{~h}$ recovery period were less able to take up [ ${ }^{3} \mathrm{H}$ ]adenosine by equilibrative mechanisms than cultures from the control group. That decrease in uptake ability could potentially increase ISF adenosine during ischemia (Redzic et al., 2010b).

\section{Transport of anti-HIV drugs by human nucleoside transporters}

Since the onset of the AIDS pandemic in 1981, infection with the human immunodeficiency virus (HIV) infection has spread exponentially throughout the world. HIV is neuro-invasive (with invasion occurring early in the course of the infection), neuro-virulent (causing a neuropathy, myopathy, myelopathy, and dementia), but it is not especially neurotrophic (Manji and Miller 2004). Several drugs are now available for treatment of HIV infection, including the following nucleoside analogues reverse transcriptase inhibitors: zidovudine (1-[(2R,4S,5S)-4-azido-5-(hydroxymethyl)oxolan-2-yl]-5-methyl-1,2,3,4-

tetrahydropyrimidine-2,4-dione), also known as 3'-azido-3'-deoxythymidine (trade name Retrovir), abacavir [4-(2-amino-6-cyclopropylamino-9H-purin-9-yl)-1- cyclopent-2enyl]methanol) ( trade name Ziagen), stavudine (1-[(2R,5S)-5-(hydroxymethyl)-2,5dihydrofuran-2-yl]-5-methyl-1,2,3,4-tetrahydropyrimidine-2,4-dione) also known as 2'-3'didehydro-2'-3'-dideoxythymidine (trade name Zerit), lamivudine (4-amino-1-[(2R,5S)-2(hydroxymethyl)-1,3-oxathiolan-5-yl]-1,2-dihydropyrimidin-2-one) also known as 2',3'dideoxy-3'-thiacytidine (trade names Zeffix, Heptovir or Epivir), emitricitabine (4-amino-5fluoro-1-[(2R,5S)-2-(hydroxymethyl)-1,3-oxathiolan-5-yl]-1,2-dihydropyrimidin-2-one), trade name Emtriva, zalcitabine (4-amino-1-[(2R,5S)-5-(hydroxymethyl)oxolan-2-yl]-1,2dihydropyrimidin-2-one) also known as 2'-3'-dideoxycytidine (trade name Hivid) and didanosine (9-[(2R,5S)-5-(hydroxymethyl)oxolan-2-yl]-6,9-dihydro-3H-purin-6-one) also known as 2',3'-dideoxyinosine (trade name Videx). Potentially, all those nucleoside analogues could be used for the neuro-HIV treatment; however, their effect on HIV replication in the brain largely depends on its ability to enter the CNS and concentrations that they can achieve in the brain ECF and in the cytoplasm. Transport across the BBB largely depends on physico-chemical characteristics of a drug (polarity, lipophilicity, molecular weight) (for the role of lipophilicity in the BBB passage see Abbott et al., 2008 and Abbott et al., 2010). Based upon their measured CSF concentrations and therapeutic effects, these anti-HIV nucleosides are classified either as high CNS penetrating drugs (zidovudine and abacavir), intermediate CNS penetrating drugs (stavudine, lamivudine and emitricitabine) or low CNS penetrating drugs (zalcitabine and didanosine) (Letendre et al., 2008).The first drug that was approved for AIDS was zidovudine. Intracellularly, this drug is phosphorylated to azidothymidine triphosphate, which then inhibits reverse transcriptase and thus impedes viral replication. This drug was partially successful in controlling replication of HIV in the brain. NTs- mediated uptake across the BBB of zidovudine is low; however, because of its lipophilic nature, it passes the BBB by a simple diffusion and then enters the cells. Thus, it appears that distribution of zidovudine in the brain fluids largely do not depend on NT- mediated transport across the BBB and CPs (Thomas and Segal., 1997). However, in vitro studies confirmed that zidovudine, zalcitabine and didanosine are substrates for several nucleoside transporters (Table 2) (Baldwin et al., 2005, Yao et al., 2001). 


\begin{tabular}{lll}
\hline RTI & $\begin{array}{l}\text { Nucleoside transporter that } \\
\text { mediate transport }\end{array}$ & Source \\
\hline Zidovudine & hENT2, hENT3, hCNT1 & $\begin{array}{l}\text { Baldwin et al., 2005, Yao et } \\
\text { al., 2001 } \\
\text { Baldwin et al., 2005, Yao et } \\
\text { al., 2001 }\end{array}$ \\
Diditabine & hENT1-3, hCNT1, hCNT3 & $\begin{array}{l}\text { Baldwin et al., 2005, Yao et } \\
\text { al., 2001 }\end{array}$ \\
\hline
\end{tabular}

Table 2. Transport of nucleoside analogues reverse transcriptase inhibitors (RTIs) by human nucleoside transporters. *The estimated Km value for hENT2 is $2.3 \mathrm{mM}$

Human ENT2, expressed in Xenopus oocytes, transports zidovudine, zalcitabine and didanosine (Yao et al., 2001). Human ENT3 (which is mainly located intracellularly) also transports these three nucleoside analogues, while hENT1 transports zalcitabine. hCNT1, which is pyrimidine nucleoside-selective, transports pyrimidine analogues zidovudine and zalcitabine, hCNT2, which is purine nucleoside-selective, transports purine analogue didanosine, while hCNT3, which is broadly selective, transports all three drugs (Smith et al., 2004, Smith et al., 2005).

\section{Conclusion}

Over the last two decades, seven separate human nucleoside transporters have been cloned and successfully produced as functional recombinant proteins in a heterologous expression system (Xenopus Laevis oocytes), which enabled their functional characterization. Findings from these studies provided the tools that were needed to better understand nucleoside transport in the brain under normal physiological conditions and under various pathophysiological conditions (e.g. ischemia / hypoxia) as well as to understand therapeutic potential of these processes. Molecular structure of equlibrative nucleoside transporters has been elucidated, but more data on clarification of concentrative nucleoside transporters molecular architecture are still needed. The roles of individual nucleoside transporters in cells that possess multiple transporter isoforms are still not being fully elucidated, which also applies to their roles in the brain. An important attempt to disentanglement the contributions of individual nucleoside transporters was done by a genetic knock-out approach, which produced mENT1-null mice. Such knowledge should provide important data required to produce nucleoside analogues reverse transcriptase inhibitors that are brain-accessible.

\section{References}

Abbott, J., Dolman, E., \& Patabendige, K. (2008). Assays to predict drug permeation across the blood-brain barrier, and distribution to brain. Current Drug Metabolism, Vol.9, No.9,(November 2008), pp. 901-10, ISSN 1389-2002

Abbott, J., Patabendige, K., Dolman, E., Yusof, R., \& Begley, J. (2010). Structure and function of the blood-brain barrier. Neurobiology of Disease, Vol.37, No.1, (January 2010), pp.13-25, ISSN 0969-9961 
Alanko, L., Porkka-Heiskanen, T., \& Soinila, S. (2006). Localization of equilibrative nucleoside transporters in the rat brain. Journal of Chemical Neuroanatomy, Vol.31,(April 2010), pp. 162-8, ISSN 0891-0618

Anderson, CM. Xiong, W. Young, JD., Cass, CE., \& Parkinson, FE. (1996). Demonstration of the existence of mRNAs encoding the N1/cif and N2/cit sodium/nucleoside cotransporters in rat brain. Molecular Brain Research, Vol.42, No.2, (December 1996), pp. 358-61, ISSN 0169-328X

Anderson, CM., Xiong, W., Geiger, JD., Young, JD. Cass, CE., Baldwin, SA., \& Parkinson, FE. (1999). Distribution of equilibrative, nitrobenzylthioinosine-sensitive nucleoside transporters (ENT1) in brain. Journal of Neurochemistry, Vol.73, No.2, (August 1999), pp. 867-73, ISSN 0022-3042

Anderson, CM.; Baldwin, SA.; Young, JD.; Cass, CE., \& Parkinson, FE. (1999). Distribution of mRNA encoding a nitrobenzylthioinosine-insensitive nucleoside transporter (ENT2) in rat brain. Molecular Brain Research, Vol.70, No.2, (July 1999), pp. 293-7, ISSN 0169-328X

Bailey, A., Matthes, H., Kieffer, B., Slowe, S., Hourani, SM., \& Kitchen, I. (2002). Quantitative autoradiography of adenosine receptors and NBTI-sensitive adenosine transporters in the brains and spinal cords of mice deficient in the mu-opioid receptor gene. Brain Research, Vol.943, No.1, (July 2002), pp. 68-79, ISSN 0006-8993

Baldwin, SA., Beal, PR., Yao, SY., King, AE., Cass, CE., \& Young, JD. (2004). The equilibrative nucleoside transporter family, SLC29. Pflugers Archiv European Journal of Physiology, Vol.447, No.5, (February 2004), pp. 735-43, ISSN 0031-6768

Baldwin, SA., Yao, SY., Hyde, RJ., Ng, AM., Foppolo, S., Barnes, K., Ritzel, MW., Cass, CE., \& Young, J.D. (2005). Functional characterization of novel human and mouse equilibrative nucleoside transporters (hENT3 and mENT3) located in intracellular membranes. Journal of Biologycal Chemistry, Vol.280, No.16, (April 2005), pp.15880-7, ISSN 0021-9258

Barnes, K., Dobrzynski, H., Foppolo, S., Beal, PR., Ismat, F., Scullion, ER., Sun, L., Tellez, J., Ritzel, MW., Claycomb, WC., Cass, CE., Young, JD., Billeter-Clark, R., Boyett, MR., \& Baldwin, SA. (2006). Distribution and functional characterization of equilibrative nucleoside transporter-4, a novel cardiac adenosine transporter activated at acidic pH. Circulation Research, Vol.99, No.5, (September 2006), pp. 510-9, ISSN 0009-7330

Bundgaard, M., \& Abbott, NJ.(2008). All vertebrates started out with a glial blood-brain barrier 4-500 million years ago. Glia, Vol.56, No.7, (May 2008), pp. 699-708, ISSN 0894-1491

Cai, G., Salonikidis, PS., Fei, J., Schwarz, W., Schülein, R., Reutter, W., \& Fan H. (2005). The role of N-glycosylation in the stability, trafficking and GABA-uptake of GABAtransporter 1. Terminal N-glycans facilitate efficient GABA-uptake activity of the GABA transporter. FEBS Journal, Vol.272, No.7, (April 2005), pp. 1625-38, ISSN 1742-464X

Cass, CE., Young, JD., \& Baldwin, SA. (1998). Recent advances in the molecular biology of nucleoside transporters of mammalian cells. Biochemistry and Cell Biology, Vol.76, No.5, (1998), pp. 761-70, ISSN 0829-8211

Che, M., Ortiz, DF., \& Arias, IM. (1995). Primary structure and functional expression of a cDNA encoding the bile canalicular, purine-specific $\mathrm{Na}$--nucleoside cotransporter. Journal of Biologycal Chemistry, Vol.270, No.23, (Jun 1995), pp. 13596-9, ISSN 00219258

Choi, DS., Cascini, MG., Mailliard, W., Young, H., Paredes, P., McMahon, T., Diamond, I., Bonci. A., \& Messing, RO. (2004). The type 1 equilibrative nucleoside transporter 
regulates ethanol intoxication and preference. Nature Neuroscience, Vol.7, No.8, (August 2004), pp. 855-61, ISSN 1097-6256

Crawford, CR., Patel, DH., Naeve, C., \& Belt, JA. (1998) Cloning of the human equilibrative, nitrobenzylmercaptopurine riboside (NBMPR)-insensitive nucleoside transporter ei by functional expression in a transport-deficient cell line. Journal of Biological Chemistry, Vol.273, No.9, (February 1998), pp. 5288-93, ISSN 0021-9258

Dahlin, A., Xia, L., Kong, W., Hevner, R., \& Wang, J. (2007). Expression and immunolocalization of the plasma membrane monoamine transporter in the brain. Neuroscience, Vol.146, No.3, (May 2007), pp. 1193-211, ISSN 0306-4522

Dunwiddie, TV., \& Masino, SA. (2001). The role and regulation of adenosine in the central nervous system. Annual Review of Neuroscience, Vol.24, (March 2001), pp. 31-55, ISSN 0147-006X

Fredholm, BB., Chen, JF., Cunha, RA., Svenningsson, P., \& Vaugeois, JM. (2005). Adenosine and brain function. International Review of Neurobiology, Vol.63, (2005), pp. 191-270, ISSN 0074-7742

Hendriks, M., Koudijs, BW., van Balkom, V., Oorschot, J., Klumperman, PM., Deen, P., \& van der Sluijs P. (2004) Glycosylation is important for cell surface expression of the water channel aquaporin-2 but is not essential for tetramerization in the endoplasmic reticulum. Journal of Biological Chemistry, Vol.279, No.4, (January 2004), pp. 2975-83, ISSN 0021-9258

Geiger, JD., \&Nagy, JI. (1984). Heterogeneous distribution of adenosine transport sites labelled by $[3 \mathrm{H}]$ nitrobenzylthioinosine in rat brain: an autoradiographic and membrane binding study. Brain Research Bulletin, Vol.13, No.5, (November 1984), pp. 657-66, ISSN 0361-9230

Gerstin, KM., Dresser, MJ., Wang, J., \& Giacomini, KM. (2000) Molecular cloning of a Na+dependent nucleoside transporter from rabbit intestine. Pharmaceutical Research, Vol.17, No.8, (August 2000), pp. 906-10, ISSN 0724-8741

Govindarajan, R., Leung, GP., Zhou, M., Tse, CM., Wang, J., \& Unadkat, JD. (2009). Facilitated mitochondrial import of antiviral and anticancer nucleoside drugs by human equilibrative nucleoside transporter-3. American Journal of Physiology Gastrointestinal and Liver Physiology, Vol.296, No.4, (April 2009), pp. G910-22, ISSN 0193-1857

Gray, JH., Owen, RP., \& Giacomini, KM. (2004) The concentrative nucleoside transporter family, SLC28. Pflugers Archive European Journal of Physiology, Vol.447, No.5, (February 2004), pp. 728-34, ISSN 0031-6768

Griffiths, M., Beaumont, N., Yao, SYM., Sundaram, M., Boumah, CE., Davies, A., Kwong, FYP., Coe, I., Cass, CE., Young, JD., \& Baldwin, SA. (1997a). Cloning of a human nucleoside transporter implicated in the cellular uptake of adenosine and chemotherapeutic drugs. Nature Medicine, Vol.3, No.1, (January 1997), pp.89-93, ISSN 1078-8956

Griffiths, M., Yao, SYM., Abidi, F., Phillips, SEV., Cass, CE., Young, JD., \& Baldwin, SA. (1997b) Molecular Cloning and characterization of a nitrobenzylthioinosineinsensitive (ei) equilibrative nucleoside transporter from human placenta. Biochemical Journal, Vol.328, (December 1997), pp. 739-43, ISSN 0264-6021

Guillen-Gomez, E., Calbet, M., Casado, J., de Lacea, L., Soriano, E., Pastor-Anglada, M., \& Burgaya, F. (2004). Distribution of CNT2 and ENT1 transcripts in rat brain: selective decrease of CNT2 mRNA in the cerebral cortex of sleep-deprived rats. Journal of Neurochemistry, Vol.90, No.4, (August 2004), pp. 883-93, ISSN 0022-3042 
Hyde, RJ., Cass, CE., Young, JD., \& Baldwin, SA. (2001) The ENT family of eukaryote nucleoside and nucleobase transporters: recent advances in the investigation of structure/function relationships and the identification of novel isoforms. Molecular Membrane Biology, Vol.18, No.1, (January-March 2001), pp. 53-63, ISSN 0968-7688

Isakovic, AJ., Abbott, NJ., \& Redzic, ZB (2004). Brain to blood efflux transport of adenosine: blood-brain barrier studies in the rat. Journal of Neurochemistry, Vol.90, No.2, (July 2004), pp. 272-86, ISSN 0022-3042

Isakovic, AJ., Segal, MB., Milojkovic, BA., Dacevic, MP., Misirlic, ST., Rakic, ML., \& Redzic, ZB. (2002). The efflux of purine nucleobases and nucleosides from the rat brain. Neuroscience Letters, Vol.318, No.2, (January 2002), pp. 65-8, ISSN 0304-3940

Jennings, LL., Hao, C., Cabrita, MA., Vickers, MF., Baldwin, SA., Young, JD., \& Cass, CE. (2001). Distinct regional distribution of human equilibrative nucleoside transporter proteins 1 and 2 (hENT1 and hENT2) in the central nervous system. Neuropharmacology, Vol.40, No.5, (April 2001), pp. 722-31, ISSN 0028-3908

Jones, KW., \& Hammond, JR. (1992). Heterogeneity of [3H]dipyridamole binding to CNS membranes: correlation with $[3 \mathrm{H}]$ nitrobenzylthioinosine binding and $[3 \mathrm{H}]$ uridine influx studies. Journal of Neurochemistry, Vol.59, No.4, (October 1992), pp. 1363-71, ISSN 0022-3042

King, AE., Ackey, MA., Cass, CE., Young, JD., \& Baldwin, SA. (2006). Nucleoside transporters: from scavengers to novel therapeutic targets. Trends in Pharmacological Sciences, Vol.27, No.8, (August 2006), pp. 416-25, ISSN 0165-6147

Lawrence, AJ., Castillo-Melendez, M., \& Jarrott, B. (1994) [3H]adenosine transport in rat dorsal brain stem using a crude synaptosomal preparation. Neurochemistry International, Vol.25, No.3, (September 1994), pp. 221-6, ISSN 0197-0186

Lee, EW., Lai, Y., Zhang, H., \& Unadkat, JD. (2006). Identification of the mitochondrial targeting signal of the human equilibrative nucleoside transporter 1 (hENT1): implications for interspecies differences in mitochondrial toxicity of fialuridine. Journal of Biological Chemistry, Vol.281, No.24, (June 2006), pp. 16700-6, ISSN 00219258

Leisewitz, AV., Zimmerman, EI., Huang, M., Jones, SZ., Yang, J., \& Graves, LM. (2011). Regulation of ENT1 expression and ENT1-dependent nucleoside transport by c-Jun N-terminal kinase. Biochemical and Biophysical Research Communication, Vol.404, No1, (January 2011), pp. 370-5, ISSN 0006-291X

Letendre, S., Marquie-Beck, J., Capparelli, E., Best, B., Clifford, D., Collier, AC., Gelman, BB., McArthur, JC., McCutchan, JA., Morgello, S, Simpson, D., Grant, I., \& Ellis, R.J. (2008). Validation of the CNS Penetration-Effectiveness rank for quantifying antiretroviral penetration into the central nervous system. Archives of Neurology, Vol.65, No.1, (2008), pp. 65-70, ISSN 0003-9942

Lu, H., Chen, C., \& Klassen, C. (2004). Tissue distribution of concentrative and equilibrative nucleoside transporters in male and female mice. Drug Metabolism and Disposition, Vol.32, No.12, (December 2004), pp. 1455-61, ISSN 0090-9556

Mani, RS., Hammond, JR., Marjan, JM., Graham, KA., Young, JD., Baldwin, SA., \& Cass, CE. (1998). Demonstration of equilibrative nucleoside transporters (hENT1 and hENT2) in nuclear envelopes of cultured human choriocarcinoma (BeWo) cells by functional reconstitution in proteoliposomes. Journal of Biological Chemistry, Vol.273, No.46, (November 1998), pp. 30818-25, ISSN 0021-9258

Manji, H., \& Miller, R. (2004). The neurology of HIV infection. Journal of Neurology Neurosurgery and Psychiatry, Vol.75, Supp.1. (Mart 2004), i29-i35, ISSN 0022-3050 
Melani, A., Pantoni, L., Corsi, C., Bianchi, L., Monopoli, A., Bertorelli, R., Pepeu, G., \& Pedata, F. (1999) Striatal outflow of adenosine, excitatory amino acids, caminobutyric acid and taurine in awake freely moving rats after middle cerebral artery occlusion. Correlation with neurological deficit and histopathological damage. Stroke, Vol.30, No.11, (November 1999), pp. 2448-55, ISSN 0039-2499

Miller, DS. (2010). Regulation of P-glycoprotein and other ABC drug transporters at the blood-brain barrier. Trends in Pharmacological Sciences, Vol. 31, No.6, (Jun 2010), pp. 246-54, ISSN 0165-6147

Moss, FJ., Imoukhuede, PI., Scott, K., Hu, J., Jankowsky, JL., Quick, MW., \& Lester, HA. (2009). GABA transporter function, oligomerization state, and anchoring: correlates with subcellularly resolved FRET. Journal of General Physiolology, Vol.134, No.6, (December 2009), pp. 489-521, ISSN 0022-1295

Nagai, K., Nagasawa, K., \& Fujimoto, S. (2005). Transport mechanisms for adenosine and uridine in primary-cultured rat cortical neurons and astrocytes. Biochemical and Biophysical Research Communication, Vol.334, No.4, (September 2005), pp. 1343-50, ISSN 0006-291X

Nivillac, NM., Bacani, J., \& Coe, IR. (2011). The life cycle of human equilibrative nucleoside transporter 1: From ER export to degradation. Experimental Cell Research, (March 2011), In press, ISSN 0014-4827

Paproski, RJ., Ng, AM., Yao, SY., Graham, K., Young, JD., \& Cass, CE. (2008). The role of human nucleoside transporters in uptake of $3^{\prime}$-deoxy-3'-fluorothymidine. Molecular Pharmacology, Vol.74, No.5, (November 2008), pp. 1372-80, ISSN 0026-895X

Parkinson, FE., \& Xiong, W. (2004). Stimulus- and cell-type-specific release of purines in cultured rat forebrain astrocytes and neurons. Journal of Neurochemistry, Vol.88, No.5, (March 2004), pp. 1305-12, ISSN 0022-3042

Parkinson, FE., Damaraju, VL., Graham, K., Yao, SY., Baldwin, SA., Cass, CE., \& Young, JD. (2011). Molecular Biology of Nucleoside Transporters and Their Distributions and Functions in the Brain. Current Topics in Medical Chemistry, (March 2011), In press, ISSN 1568-0266

Parkinson, FE., Ferguson, J., Zamzow, CR., \& Xiong, W. (2006). Gene expression for enzymes and transporters involved in regulating adenosine and inosine levels in rat forebrain neurons, astrocytes and C6 glioma cells. Journal of Neuroscience Research, Vol.84, No.4, (September 2006), pp. 801-8, ISSN 0360-4012

Parkinson, FE., Johansson, B., Lindström, K., \& Fredholm, BB. (1996). Adenosine A1 and A2a receptors and nitrobenzylthioinosine-sensitive transporters in gerbil brain: no changes following long-term treatment with the adenosine transport inhibitor propentofylline. Neuropharmacology, Vol.35, No.1, (January 1996), pp. 79-89, ISSN 0028-3908

Parkinson, FE., Xiong, W., \& Zamzow, CR. (2005). Astrocytes and neurons: different roles in regulating adenosine levels. Neurological Research, Vol.27, No.2, (2005), pp. 153-60, ISSN 0161-6412

Patel, DH., Crawford, CR., Naeve, CW., \& Belt, JA. (2000) Cloning, genomic organization and chromosomal localization of the gene encoding the murine sodium-dependent, purine-selective, concentrative nucleoside transporter (CNT2). Gene, Vol.242, No.12, (January 2000), pp. 51-8, ISSN 0378-1119

Peng, L., Huang, R., Yu, AC., Fung, KY., Rathbone, MP., \& Hertz, L. (2005). Nucleoside transporter expression and function in cultured mouse astrocytes. Glia, Vol.52, No.1, (October 2005), pp. 25-35, ISSN 0894-1491 
Phillips, E., \& Newsholme, EA. (1979). Maximum activities, properties and distribution of $5 \$$-nucleotidase, adenosine kinase and adenosine deaminase in rat and human brain. Journal of Neurochemistry, Vol.33, No.2, (August 1979), pp. 553-8, ISSN 00223042

Redzic, Z. (2011). Molecular biology of the blood-brain and the blood-cerebrospinal fluid barriers: similarities and differences. Fluids and Barriers of the CNS, Vol.8, No. 1, (January 2011), pp. 3

Redzic, ZB., Biringer, J., Barnes, K., Baldwin, SA., Al-Sarraf, H., Nicola, PA., Young, JD., Cass, CE., Barrand, MA., \& Hladky, SB. (2005). Polarized distribution of nucleoside transporters in rat brain endothelial and choroid plexus epithelial cells. Journal of Neurochemistry, Vol.94, No.5, (September 2005), pp. 1420-6, ISSN 0022-3042

Redzic, ZB., Isakovic, AJ., Misirlic Dencic, ST., Popadic, D., \& Segal, MB. (2006) Uneven distribution of nucleoside transporters and intracellular enzymatic degradation prevent transport of intact $\left[{ }^{14} \mathrm{C}\right]$ adenosine across the sheep choroid plexus epithelium as a monolayer in primary culture. Cerebrospinal Fluid Research, Vol.29., No.3 (March 2006), pp.1, ISSN 1743-8454

Redzic, ZB., Malatiali, SA., Al-Bader, M., \& Al-Sarraf, H. (2010b) Effects of hypoxia, glucose deprivation and recovery on the expression of nucleoside transporters and adenosine uptake in primary culture of rat cortical astrocytes. Neurochemistry Research, Vol.35, No.9, (September 2010), pp. 1434-44

Redzic, ZB., Malatiali, SA., Grujicic, D., \& Isakovic, AJ. (2010a). Expression and functional activity of nucleoside transporters in human choroid plexus. Cerebrospinal Fluid Research, Vol. 7, No.2 (January 2010), ISSN1743-8454

Reichel, A., Begley, DJ., \& Abbott, NJ. (2003) An overview of in vitro techniques for bloodbrain barrier studies. Methods in Molecular Medicine, Vol.89, (2003), pp. 307-24, ISSN 1543-1894

Ritzel, MW., Ng, AM., Yao, SY., Graham, K., Loewen, SK., Smith, KM., Ritzel, RG., Mowles, DA., Carpenter, P., Chen, XZ., Karpinski, E., Hyde, RJ., Baldwin, SA., Cass, CE., \& Young, JD. (2001). Molecular identification and characterization of novel human and mouse concentrative Nat-nucleoside cotransporter proteins (hCNT3 and mCNT3) broadly selective for purine and pyrimidine nucleosides (system cib). Journal of Biological Chemistry, Vol.276, No.4, (January 2001), pp. 2914-27, ISSN 00219258

Ritzel, MW., Yao, SY., Huang, MY., Elliott, JF., Cass, CE., \& Young, JD. (1997). Molecular cloning and functional expression of cDNAs encoding a human $\mathrm{Na}+$-nucleoside cotransporter (hCNT1). American Journal of Physiology, Vol.272, No.2, (February 1997), pp. C707-14, ISSN 0002-9513

Ritzel, MW., Yao, SY., Ng, AM., Mackey, JR., Cass, CE., \& Young, JD. (1998) Molecular cloning, functional expression and chromosomal localization of a cDNA encoding a human $\mathrm{Na}+$ /nucleoside cotransporter (hCNT2) selective for purine nucleosides and uridine. Molecular Membrane Biology, Vol.15, No. (October-December 1998), pp. 203-11, ISSN 0968-7688

Rose, JB., Naydenova, Z., Bang, A., Eguchi, M., Sweeney, G., Choi, DS., Hammond, JR., \& Coe, IR. (2010). Equilibrative nucleoside transporter 1 plays an essential role in cardioprotection. American Journal of Physiology and Heart Circulatory Physiology, Vol.298, No.3, (March 2010), pp. H771-7, ISSN 0363-6135

Slugoski, MD., Loewen, SK., Ng, AML., Smith, KM., Yao, SYM., Karpinski, E., Cass, CE., Baldwin, SA., \& Young, JD. (2007) Residue mutations in transmembrane helix 8 of human concentrative $\mathrm{Na}^{+}$/nucleoside cotransporter hCNT1 affect permeant 
selectivity and cation coupling. Biochemistry, Vol. 46, No. 6, (February 2007), pp. 1684-93, ISSN 0006-2960

Slugoski, M D., Smith, K M., Mulinta, R., Ng, AML., Yao, SYM., Morrison, EL., Lee, QOT., Zhang, J., Karpinski, E., Cass, CE., Baldwin, SA., \& Young, JD. (2008) A conformationally mobile cysteine residue (Cys-561) modulates $\mathrm{Na}+$ and $\mathrm{H}^{+}$ activation of human CNT3. Journal of Biological Chemistry, Vol. 283, No. 36, (September 2008), pp. 24922-34, ISSN 0021-9258

Smith, KM., Ng, AM., Yao, SY., Labedz, KA., Knaus, EE., Wiebe, LI., Cass, CE., Baldwin, SA., Chen, XZ., Karpinski, E., \& Young, JD. (2004). Electrophysiological characterization of a recombinant human $\mathrm{Na}$-coupled nucleoside transporter (hCNT1) produced in Xenopus oocytes. Journal of Physiology, Vol.558,(August 2004), pp. 807-23, ISSN 0022-3751

Smith, KM., Slugoski, MD., Cass, CE., Baldwin, SA., Karpinski, E., \& Young, JD. (2007). Cation coupling properties of human concentrative nucleoside transporters hCNT1, hCNT2 and hCNT3. Molecular Membrane Biology, Vol.24, No.1, (January-February 2007), pp. 53-64, ISSN 0968-7688

Smith, KM., Slugoski, MD., Loewen, SK., Ng, AM., Yao, SY., Chen, XZ., Karpinski, E., Cass, CE., Baldwin, SA., \& Young, JD. (2005). The broadly selective human $\mathrm{Na}+$ /nucleoside cotransporter (hCNT3) exhibits novel cation-coupled nucleoside transport characteristics. Journal of Biolgycal Chemistry, Vol.280, No.27, (July 2005), pp. 25436-49, ISSN 0021-9258

Tanaka, K., Xu, W., Zhou, F., \& You, G. (2004). Role of glycosylation in the organic anion transporter OAT1. Journal of Biological Chemistry, Vol.279, No.15, (April 2004), pp. 14961-6, ISSN 0021-9258

Thomas, SA., \& Segal, MB. (1997). The passage of azidodeoxythymidine into and within the central nervous system: does it follow the parent compound, thymidine? Journal of Pharmacology and Experimental Therapeutics, Vol.281, No.3, (Jun 1997), pp. 1211-8, ISSN 0022-3565

Torres, M., Delicado, EG., Fideu, MD., \& Miras-Portugal, MT. (1992). Down-regulation and recycling of the nitrobenzylthioinosine-sensitive nucleoside transporter in cultured chromaffin cells, Biochemica et Biophysica Acta, Vol.1105, No.2, (April 1992), pp. 2919 ,

Vialou, V., Balasse, L., Dumas, S., Giros, B., \& Gautron, S. (2007). Neurochemical characterization of pathways expressing plasma membrane monoamine transporter in the rat brain. Neuroscience, Vol.144, No.2, (January 2007), pp. 616-22, ISSN 03064522

Visser, F., Sun, L., Baldwin, SA., Young, JD., \& Cass, CE. (2007). Residues 334 and 338 in transmembrane segment 8 of human equilibrative nucleoside transporter 1 are important determinants of inhibitor sensitivity, protein folding and catalytic turnover. Journal of Biological Chemistry, Vol.282, No.19, (May 2007), pp. 14148-57, ISSN 0021-9258

Visser, F., Vickers, MF., Ng, AM., Baldwin, SA., Young, JD., \& Cass, CE. (2002). Mutation of residue 33 of human equilibrative nucleoside transporters 1 and 2 alters sensitivity to inhibition of transport by dilazep and dipyridamole. Journal of Biological Chemistry, Vol.277, No.1, (January 2002), pp. 395-401, ISSN 0021-9258

Wang, J., Su, SF., Dresser, MJ., Schaner, ME., Washington, CB., \& Giacomini, KM. (1997) $\mathrm{Na}$-dependent purine nucleoside transporter from human kidney: cloning and functional characterization. American Journal of Physiology, Vol.273, No.6, (December 1997), pp. F1058-65, ISSN 0363-6127 
Yao, SY., Ng, AM., Sundaram, M., Cass, CE., Baldwin, SA., \& Young, JD. (2001). Transport of antiviral 3'-deoxy-nucleoside drugs by recombinant human and rat equilibrative, nitrobenzylthioinosine (NBMPR)-insensitive (ENT2) nucleoside transporter proteins produced in Xenopus oocytes. Molecular Membrane Biology, Vol.18, No.2, (April-Jun 2001), pp. 161-7, ISSN 0968-7688

Yao, SY., Ng, AM., Vickers, MF., Sundaram, M., Cass, CE., Baldwin, SA., \& Young, JD. (2002) Functional and molecular characterization of nucleobase transport by recombinant human and rat equilibrative nucleoside transporters 1 and 2 . Chimeric constructs reveal a role for the ENT2 helix 5-6 region in nucleobase translocation. Journal of Biological Chemistry, Vol.277., No.28, (July 2002), pp. 24938-48, ISSN 00219258

Young, JD., \& Jarvis, SM. (1983). Nucleoside transport in animal cells. Bioscience Reports, Vol.3, No.4, (April 1983), pp. 309-22, ISSN 0144-8463

Zamzow, CR., Bose, R., \& Parkinson, FE. (2009). N-methyl-D-aspartate-evoked adenosine and inosine release from neurons requires extracellular calcium. Canadian Journal of Physiology and Pharmacology, Vol.87, No.10, (October 2009), pp. 850-8, ISSN 00084212

Zamzow, CR., Xiong, W., \& Parkinson, FE. (2008) Adenosine produced by neurons is metabolized to hypoxanthine by astrocytes. Journal of Neuroscience Research, Vol. 86, No.15, (November 2008), pp. 3447-55, ISSN 0360-4012

Zhang, D., Xiong, W., Albensi, BC., \& Parkinson, FE. (2011). Expression of human equilibrative nucleoside transporter 1 (hENT1) in mouse neurons regulates adenosine levels in physiological and hypoxic-ischemic conditions. Journal of Neurochemistry, (March 2011), In press, ISSN 0022-3042

Zhang, J., Visser, F., King, KM., Baldwin, SA., Young, JD., \& Cass, CE. (2007) The role of nucleoside transporters in cancer chemotherapy with nucleoside drugs. Cancer Metastasis Reviews, Vol.26, No.1, (2007), pp. 85-110, ISSN 0167-7659

Zhang, Q., Hong, M., Duan, P., Pan, Z., Ma, J., \& You G. (2008). Organic anion transporter OAT1 undergoes constitutive and protein kinase C-regulated trafficking through a dynamin- and clathrin-dependent pathway. Journal of Biological Chemistry, Vol.283, No.47, (November 2008), pp. 32570-9, ISSN 0021-9258

Zhou, M., Engel, K., \& Wang, J. (2007) Evidence for significant contribution of a newly identified monoamine transporter (PMAT) to serotonin uptake in the human brain. Biochemical Pharmacology, Vol.73, No.1, (January 2007), pp. 147-54, ISSN 0006-2952 


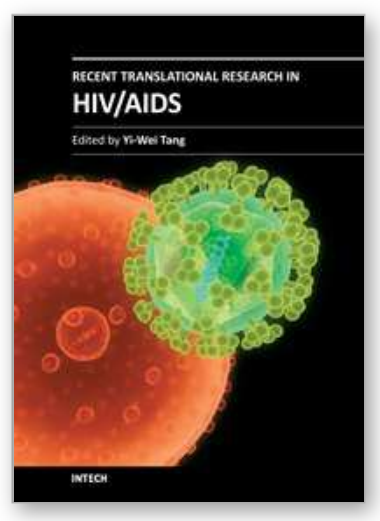

\author{
Recent Translational Research in HIV/AIDS \\ Edited by Prof. Yi-Wei Tang
}

ISBN 978-953-307-719-2

Hard cover, 564 pages

Publisher InTech

Published online 02, November, 2011

Published in print edition November, 2011

The collective efforts of HIV/AIDS research scientists from over 16 countries in the world are included in the book. This 27-chapter Open Access book well covers HIV/AIDS translational researches on pathogenesis, diagnosis, treatment, prevention, and also those beyond conventional fields. These are by no means inclusive, but they do offer a good foundation for the development of clinical patient care. The translational model forms the basis for progressing HIV/AIDS clinical research. When linked to the care of the patients, translational researches should result in a direct benefit for HIV/AIDS patients.

\title{
How to reference
}

In order to correctly reference this scholarly work, feel free to copy and paste the following:

Zoran B. Redzic and Sonja Misirlic Dencic (2011). Transport Mechanisms of Nucleosides and Nucleoside Analogues ReverseTranscriptase Inhibitors in the Brain, Recent Translational Research in HIV/AIDS, Prof. YiWei Tang (Ed.), ISBN: 978-953-307-719-2, InTech, Available from: http://www.intechopen.com/books/recenttranslational-research-in-hiv-aids/transport-mechanisms-of-nucleosides-and-nucleoside-analoguesreversetranscriptase-inhibitors-in-the-

\section{INTECH}

open science | open minds

\section{InTech Europe}

University Campus STeP Ri Slavka Krautzeka 83/A 51000 Rijeka, Croatia Phone: +385 (51) 770447

Fax: +385 (51) 686166 www.intechopen.com

\section{InTech China}

Unit 405, Office Block, Hotel Equatorial Shanghai No.65, Yan An Road (West), Shanghai, 200040, China 中国上海市延安西路65号上海国际贵都大饭店办公楼405单元 Phone: +86-21-62489820

Fax: $+86-21-62489821$ 
(C) 2011 The Author(s). Licensee IntechOpen. This is an open access article distributed under the terms of the Creative Commons Attribution 3.0 License, which permits unrestricted use, distribution, and reproduction in any medium, provided the original work is properly cited. 